\title{
RELASI PEMUDA ISLAM DAN MEDIA SOSIAL DALAM MEMBANGUN SOLIDARITAS SOSIAL
}

\section{Tsulis Amiruddin Zahri, Putri Handayani Lubis, Syaifuddin Ahrom Mahasiswa Ketahanan Nasional}

\author{
Sekolah Kajian Stratejik dan Global \\ Universitas Indonesia \\ putrihandayani.lubis90@gmail.com
}

\begin{abstract}
ABSTRAK
Studi ini mendiskripsikan konstruksi solidaritas sosial yang dibangun oleh pemuda Islam di Indonesia melalui media sosial. Peneliti dalam menyusun penelitian ini menggunakan analisis tematik dan kepustakaan yang berhubungan dengan tema penelitian. Islam sebagai agama memiliki nilai universal dalam membangun solidarita sosial melalui ajaran bahwa orang-orang mukmin bagaikan satu tubuh, yang saling terkait. Perumpamaan yang disampaikan oleh Nabi Muhammad SAW yang diriwayatkan oleh Muslim tersebut menjadi modal sosial bahwa islam bisa menjadi agen persatuan di negara Indonesia. Melihat fenomena arus informasi yang begitu mudah di media sosial, tentunya diharapkan pesan persatuan tersebut mampu menggerakkan pemuda islam yang sekarang menguasai dunia maya untuk membangun solidaritas sosial menuju Ketahanan Nasional.
\end{abstract}

\section{Kata Kunci : Solidaritas Sosial, Pemuda Islam, Ketahanan Nasional}

\section{A. Pendahuluan}

Penganut agama mayoritas di Indonesia adalah Islam. Zuhri (2011) mengatakan bahwa ada tantangan kebangsaan yang dihadapi bangsa Indonesia ketika menyepakati Republik Indonesia, yakni perasaan saling terikat. Ada kelompok Islam yang ingin menggunakan ajaran agama sebagai dasar negara, sedangkan kelompok Islam lainnya ingin menggunakan ideologi yang bisa diterima oleh semua golongan dan agama, yaitu Pancasila. Hal tersebut hingga sekarang masih menjadi perdebatan, apalagi dengan munculnya media sosial yang berkembang begitu cepat. Bahkan menurut data APJII 2017 menyebutkan bahwa dari 262 juta jiwa atau sekitar 54,68 persen adalah pengguna internet. Periode 2007-2017 tercatat kenaikan signifikan yang awalnya 20 juta pengguna menjadi 143,26 juta pengguna internet. Usia 13-34 mendominasi dengan angka 66.2 persen mengakses internet. Sedangkan akses internet yang mereka sering gunakan 
adalah media sosial sebanyak 87,13 persen. Hal yang menarik bagi penulis, ternyata konten informasi terkait sosial politik, ternyata yang sering diakses adalah artikel tentang keagamaan sebanyak 41,55 persen, berada pada urutan kedua setelah berita politik/lingkungan.

Fakta tersebut menunjukkan bahwa pembahasan mengenai agama menarik bagi masyarakat maya. Apabila dikaitkan dengan hasil survey dari We Are Social tahun 2018 memuat data bahwa rata-rata orang Indonesia menghabiskan tiga jam 23 menit sehari untuk mengakses media sosial. Instagram adalah media sosial yang memiliki jumlah pengguna terbanyak nomor tiga di dunia setelah Facebook dan Youtube, atau sebanyak 800 juta pengguna dan 20 persen dari total tersebut pengguna aktif per bulannya ada di Indonesia. Sehingga menempatkan Indonesia sebagai negara urutan ketiga sebagai pengguna media sosial Instagram.

Masalahnya, apakah data tersebut dimanfaatkan dengan baik untuk membangun pesan solidaritas sosial yang mampu menjaga Ketahanan Nasional di Indonesia. Sedangkan ketika kita melihat berbagai pemberitaan di media massa atau hal-hal yang viral di media sosial, telah banyak kerusuhan yang mengatasnamakan agama. Bahkan wilayah perdebatan agama dan rumah ibadah menjadi hal sensitive yang seirng memicu konflik sosial. Berdasarkan pemberitaan di media massa (Rochmanudin, 2018) menyebutkan bahwa sepanjang tahun 2018 telah terjadi berbagai perilaku intoleran dengan merusak dan melakukan penganiayaan terhadap tokoh agama. Pertama, kasus perusakan Pura di Lumajang Jawa Timur, tiga Acra telah dihancurkan oleh orang yang tidak dikenal. Kedua, penyerangan terhadap kiai di Lamongan, Abdul Hakam Mubarok yang merupakan pengasuh Pondok Pesantren di Karangasem Paciran Lamongan. Ketiga, Perusakan Masjid di Tuban. Keempat, ancaman bom di Kelenteng Kwan Tee Koen daerah Karawang. Kelima, serangan terhadap Gereja Santa Lidwina di Sleman Yogyakarta.

Lima kasus tersebut menjadi perhatian khusus pemerintah. Kepala Staf TNI Angkatan Darat (Kasad) Jenderal Mulyono mengatakan bahwa ancaman serius yang dihadapi sekarang adalah masalah perpecahan bangsa (Wardi, 2018). Sekarang bangsa Indonesia berjuang menghadapi ancaman yang berpotensi 
merusak persatuan dan kedaulatan. Mulyono (Wardi, 2018) mengatakan berdasarkan hasil keluaran Indeks Ketahanan Nasional Lemhannas dan Survei Kerentanan Negara dari The Fund for Peace pada Tahun 2017, menunjukkan bahwa Indonesia berada pada kategori rawan dan waspada. Hal tersebut dikarenakan tingkat pendidikan rata-rata masyarakat Indonesia adalah 8 tahun atau setingkat dengan kelas 2 SMP. Sedangkan sekarang lebih dari 130 juta dari 260 juta penduduk Indonesia merupakan pengguna aktif internet dan media sosial. Data-data statistik tersebut menunjukkan relasi linier antara kerawanan bangsa Indonesia dengan kekurangsiapan Sumber Daya Manusia (SDM) untuk menghadapi derasnya gelombang informasi yang mengiringi pesatnya perkembangan teknologi.

Menurut Khanis Suvianita (Riski, 2018) seorang aktivis dan mahasiswi program S3 untuk studi antar agama, banyaknya peredaran berita hoaks tidak bisa dilepaskan dari pihak yang bertindak sebagai pembuat atau penyebar berita hoaks. Apabila dilihat dari sisi psikologis, pembuat dan penyebar berita hoaks merupakan orang ingin popular dan diakui keberadaannya dalam masyarakat melalui sesuatu yang ia hasilkan atau bagikan. Orang itu secara natural ingin diakui, diketahui, dan dilihat. Demokrasi yang sejalan dengan adanya sosial media memberi ruang, karena seseorang bisa membuat berita, narasi, dan cerita, lalu dibagikan.

Hal yang mendukung, Adven Sarbani (Riski, 2018) selaku coordinator Mayarakat Anti Fitnah Indonesia (Mafindo) Cabang Surabaya, menyebutkan bahwa hoaks menjadi isu yang berbahaya dalam hidup berbangsa dan bermasyarakat. Isu Suku, Agama, Ras, dan Antar golongan hingga ujaran kebencian menjadi materi berbahaya dalam penyebaran berita hoaks, terutama memasuki tahun politik menjelang pemilu 2019. Adven (Riski, 2018) menegaskan pentingnya peran serta pemerintah maupun masyarakat untuk mengatasi dan mengantisipasi bahaya hoaks, dengan melakukan klarifikasi berita yang benar kepada masyarakat. Pemerintah harus pro aktif, semua pemangku kepentingan, media, semuanya harus merasa bertanggung jawab untuk mengendalikan, untuk mengantisipasi, untuk juga mengklarifikasi. Bahwa suatu isu itu segera, jangan

VOLUME 1, NO. 2 Juli - Desember 2019 
sampai menyebar terlalu lama, jangan sampai hitungan hari, hitungan jam segera harus ada klarifikasi, kebenarannya seperti apa, dan mendudukkan pada tempat yang semestinya.

Idealnya, perkembangan teknologi informasi khususnya munculnya media sosial merupakan anugerah besar bagi manusia dalam mendidik dan mengembangkan ilmu pengetahuan secara global (geotimes.co.id, 2018). Sekarang ada ruang bagi manusia dari berbagai belahan dunia untuk bebas saling mengenal, bertukar pikiran, dan berdiskusi tanpa dihalangi oleh tingkat kekayaan, bahasa, budaya, atau pun politik. Keberadaan media sosial seperti Facebook, Instagram, atau Twitter ibarat mimpi apabila kita berkaca pada masa lampau. Media sosial adalah tempat berbaur berbagai macam pikiran, seharusnya Indonesia bisa memanfaatkannya untuk meraih salah satu nilai tertinggi di Indonesia, yaitu Bhinneka Tunggal Ika dan hak merdeka untuk berpendapat. Namun sayang, pengguna media sosial masih Indonesia cenderung hanya mengedepankan hak untuk berpendapat tanpa mempedulikan nilai Bhinneka Tunggal Ika (geotimes.co.id, 2018).

Bhinneka Tunggal Ika merupakan semboyan bangsa Indonesia dari Pancasila yang berarti "berbeda-beda tetapi tetap satu," bermakna bahwa walaupun beranekaragam, Indonesia tetaplah satu. Sayang, media sosial tidak jarang digunakan untuk memaki, mengejek, bahkan mengancam karena mempunyai perbedaan. Padahal, perbedaan suku, ras, agama, budaya, atau pun pandangan politik adalah hal yang akan terjadi di Indonesia dengan jumlah penduduk terbanyak ke-4 di dunia.

Tidak harus melihat berita politik atau isu kontroversial. Saat Atlit Asian Games Jonathan Christie mengunggah foto dan kutipan ayat agama melalui akun Instagram @jonathanchristieoffical (29/08/2018), terjadi perdebatan dan kebencian antaragama di kolom kometar yang berisikan 47.000 komentar lebih. Unggahan rasa syukur kemenangan Asian Games saja dapat memancing perdebatan agama. Detik.com memberitakan ada 5.061 kasus cyber crime atau kejahatan siber yang ditangani Polri di tahun 2017 lalu, 3.325 kasus di antarannya adalah ujaran kebencian. Ujaran kebencian adalah pernyataan yang menyerang 
seseorang atau kelompok dengan karasteristik dasar, seperti SARA (Suku, Agama, Ras, dan Antargolongan).

Menyambut Pilpres 2019, tidak heran bila keadaan politik akan semakin memanas. Media sosial cenderung bukan digunakan sebagai tempat bertukar pikiran, tetapi tempat politik dengan kampanye hitam yang identik dengan menjatuhkan lawan melalui ujaran kebencian. Sebagai referensi mengukur potensi panasnya Pilpres 2019, bisa memakai contoh Pilkada DKI Jakarta 2017.

Setelah Pilkada DKI Jakarta 2017, TheGuardian, media surat kabar Inggris, melaporkan berita mengenai unsur kesengajaan penyebaran informasi palsu dan ujaran kebencian di media sosial dalam pilkada DKI Jakarta 2017. Oknum penyebar konten negatif tersebut ada di dalam kedua kubu politik pemilihan tersebut, yaitu pihak pemerintah dan pihak oposisi. Melalui artikel 'I felt disgusted': inside Indonesia's fake Twitter account factories (23/07/2018), TheGuardian menyebutkan adanya keberadaan oknum "Tim Buzzer" untuk membantu menyebarkan informasi palsu seputar Basuki Tjahaja Purnama atau 'Ahok'. "Tim Buzzer” merupakan kelompok yang bertugas memperkuat pesan dan menimbulkan "buzz" di media sosial melalui akun palsu.

Tim berjumlah 20 orang mempunyai lima akun Facebook, lima akun Twitter, dan satu akun Instagram, bahkan membuat 2.400 unggahan di Twitter setiap hari. Unggahan tersebut berisikan citra Ahok, sekaligus ujaran kebencian kepada pihak oposisi. Tim Buzzer ini digaji Rp4.000.000,00 per bulan. Tidak hanya membahas Tim Buzzer Ahok, TheGuardian juga membahas Muslim Cyber Army (MCA) yang cenderung berpihak ke oposisi. Artikel Muslim Cyber Army: a 'fake news' operation designed to derail Indonesia's leader (13/03/2018) memberitakan MCA menjadi tersangka menyebarkan informasi palsu dan ujaran kebencian di media sosial dengan isu agama dan etnis untuk membantu melengserkan Ahok pada pilkada yang sama. MCA juga menjadi tersangka sebagai pelaku pemburuan karena melakukan persekusi kepada pendukung Ahok dengan doxxing, yaitu mencari nama dan alamat asli dengan Facebook, kemudian memperkusi pendukung Ahok secara beramai-ramai di dunia nyata. 
Kasus pilkada DKI Jakarta 2017 adalah bukti bahwa informasi palsu dan ujaran kebencian sangat terorganisir di media sosial. Hal ini sangat berbahaya karena mempengaruhi masyarakat untuk membenci, bahkan membenarkan persekusi kekerasan dengan mentalitas “Us vs Them”. Inilah contoh 'kekuatan' media sosial dalam menyebarkan kebencian, terutama berlatarbelakang politik. Padahal, perbedaan pandangan politik adalah hal yang sangat wajar di lingkungan demokrasi.

Menurut Antonny Liem (Mahmud, 2016), seorang pendiri PT Merah Cipta Media mengatakan bahwa masyarakat Indonesia sangat aktif bermedia sosial. Sebanyak 93 persen dari pengguna internet di Indonesia, aktif mengakses Facebook. Bahkan Jakarta tercatat sebagai pengguna Twitter terbanyak, hingga disebut sebagai ibukota media sosial berbasis teks 140 karakter tersebut.

Sebenarnya, sudah ada Pancasila yang menjadi perekat bangsa. Sayangnya, gaung tersebut sekarang tampaknya redup. Sehingga peneliti memandang perlu untuk mencari jalan lain membangun solidaritas sosial melalui media sosial yang digerakkan atau ditujukan oleh pemuda islam. Berbagai ancaman teroris dan berkembangnya faham radikal yang mengancam ketahanan Nasional di Indonesia.

\section{B. Metode Penelitian}

Penelitian ini menggunakan pendekatan kualitatif berupa studi dokumentasi dengan analisis tematik pada postingan salah satu akun Instagram dan Twitter. Tema analisis yang dijelaskan meliputi tentang respon pemuda Islam terhadap solidaritas sosial, dialog islam dan persatuan bangsa, dan harmonisasi islam dengan kebhinnekaan yang ada di Indonesia.

Dokumen yang dianalisis adalah postingan akun Instagram dan Twitter yang berkaitan dengan solidaritas sosial dan agama islam. Analisis data menggunakan tahapan analisis tematik yakni diidentifikasi, dikodekan secara induktif (data driven) dari data kualitatif mentah (transkrip wawancara, biografi, rekaman video, dan sebagainya) maupun secara deduktif (theory driven) berdasarkan teori maupun hasil penelitian terdahulu (Boyatzis, 1998) 


\section{Pembahasan}

\section{Islam dan Solidaritas Sosial Emil Durkheim}

Durkheim (1933) memiliki pandangan tentang agama yang paling dasar dan mendasar dalam suatu budaya. Durkheim berangkat untuk melakukan dua hal, menetapkan fakta bahwa agama tidak diilhami secara ilahi atau super alami dan pada kenyataannya merupakan produk masyarakat. Durkheim juga berusaha mengidentifikasi hal-hal umum yang ditekankan oleh agama, serta apa dampak kepercayaan agama itu terhadap kehidupan semua orang dalam suatu masyarakat. Termasuk pandangannya mengenai agama sebagai solidaritas mekanik dan solidaritas organik. Berbagai lapisan masyarakat bekerja layaknya "perekat sosial" yang berupa nilai, adat istiadat dan kepercayaan yang dianut bersama.

Solidaritas mekanis dimaknai sebagai orang yang diikat dalam bentuk solidaritas yang memiliki "kesadaran kolektif" yang sama dan kuat. Oleh sebab itu individualitas tidak berkembang. Misalnya, adalah masyarakat masyarakat praindustri dan masyarakat pedesaan. Sedangkan ketika masyarakat semakin kompleks melalui pembagian kerja, solidaritas mekanik runtuh digantikan dengan solidaritas organik. Ketika hal tersebut terjadi, maka pembagian kerja akan timbul spesialisasi yang menimbulkan ketergantungan setiap oramg. Hal ini juga menggairahkan orang untuk meningkatkan kemampuannya secara personal sehingga "kesadaran koletif" semakin redup kekuatannya. Dan solidaritas ini ada pada masyarakat Industri.

Maka itu Durkheim mengusulkan pentingnya suatu konsensus intelektual dan moral untuk keteraturan sosial yang bersifat harmonis dan integratif. Munculnya istilah fakta sosial diperkenalkan oleh Emile Durkheim. Ia memberi definsi fakta sosial sebagai suatu metode tindakan tetap atau sementara yang mempunyai kendala dari luar (constraint); atau dengan kata lain sesuatu cara bertindak yang lazim dalam suatu masyarakat berwujud dengan sendirinya bebas dari manifestasi personal. Ada beberapa istilah yang terkait dengan konsep solidaritas sosial yang dibangun oleh Durkheim, diantarnya integrasi sosial dan kekompakan sosial. Secara sederhana, fenomena tersebut menunjuk pada sebuah situasi atau keadaan hubungan antar personal atau kelompok yang didasarkan pada perasaan moral dan 
kepercayaan yang diikuti bersama dan diperkuat oleh pengalaman emosional bersama.

Analisis Durkheim, perdebatan mengenai solidaritas dikaitkan dengan persoalan sanksi yang diberikan ke warga yang melanggar peraturan dalam masyarakat. Bagi Durkhem elemen yang paling jelas untuk solidaritas mekanik yaitu ruang lingkup dan kerasnya hukum-hukum di masyarakat yang sifatnya represif. Hukum tersebut mendefinisikan setiap perilaku penyimpangan sebagai sesuatu yang jahat, yang mengancam kesadaran kolektif masyarakat. Hukuman represif tersebut sekaligus bentuk pelanggaran moral oleh masing-masing orang maupun kelompok terhadap keteraturan sosial.

Sanksi dalam masyarakat dengan karakteristik solidaritas mekanik tidak dimaksudkan sebagi suatu proses rasional, melainkan mempresentasikan pertimbangan rasional dalam masyarakat. Hukum represif dalam masyarakat mekanik tidak berupa petimbangan yang diberikan yang sesuai dengan bentuk kejahatannya.

Pelanggaran terhadap kesadaran kolektif merupakan bentuk penyimpangan dari homogenitas dalam masyarakat. Karena dalam analisa Durkheim, ciri khas yang paling penting dari solidaritas mekanik itu terletak pada tingkat homogenitas yang tinggi dalam kepercayaan, sentimen, dan sebagainya. Model solidaritas seperti ini biasa ditemukan dalam masyarakat primitif atau masyarakat tradisional yang masih sederhana. Dalam masyarakat seperti ini pembagian kerja hampir tidak terjadi. Seluruh kehidupan dipusatkan pada sosok kepala suku. Pengelolaan kepentingan kehidupan sosial bersifat personal. Keterikatan sosial terjadi karena kepatuhan terhadap nilai-nilai tradisional yang dianut oleh masyarakat. Demikian juga sistem kepemimpinan yang dilaksanakan berjalan secara turun-temurun.

Gambaran solidaritas sosial dalam konteks masyarakat dapat muncul dalam berbagai kategori atas dasar karakteristik sifat atau unsur yang membentuk solidaritas itu sendiri. Durkheim membedakan solidaritas sosial dalam dua kategori; pertama, solidaritas mekanis, terjadi dalam masyarakat yang dicirikhaskan oleh keseragaman hubungan sosial, dilatarbelakangi atas kesamaan pekerjaan dan kedudukan anggota. Lalu nilai-nilai budaya yang melandasi relasi 
mereka, menyatukan mereka yang berdampak akan memunculkan ikatan sosial. Individu meleburkan diri dalam perkumpulan, hingga tidak ada bidang kehidupan yang tidak diseragamkan oleh hubungan sosial yang sama. Individu melibatkan diri secara penuh dalam kebersamaan pada masyarakat hingga tidak terbayang bahwa hidup mereka masih berarti atau dapat berlangsung, apabila salah satu aspek kehidupan diceraikan dari kebersamaan.

Singkatnya, solidaritas mekanik ditekankan pada kesadaran kolektif yang dipraktikkan masyarakat dalam bentuk kepercayaan dan sentimen penuh diantara masyarakat. Individu dalam masyarakat seperti ini cenderung homogen dalam banyak hal. Keseragaman tersebut berlangsung terjadi dalam seluruh aspek kehidupan, baik sosial, politik bahkan kepercayaan atau agama.

Apa yang dijelaskan oleh Durkheim di atas, sebenarnya sejalan dengan pemahaman Islam mengenai solidaritas sosial, atau yang biasa dikenal dengan istilah Ukhuwah. Perumpamaan Umat Islam sebagaimana digambarkan Rasulullah Saw. bagaikan satu tubuh. Hadits Rasul yang diriwayatkan oleh Nu'man bin Basyir berbunyi:

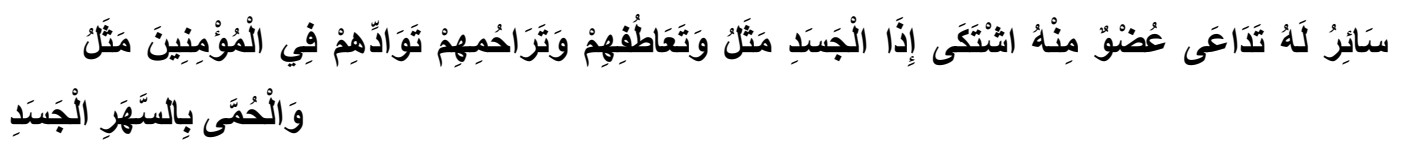

Artinya: Perumpamaan orang-orang mukmin dalam hal kasih sayang bagaikan satu tubuh, apabila satu anggota badan merintih kesakitan maka sekujur badan akan merasakan panas dan demam. (HR. Muslim).

Bila seorang atau sekelompok mukmin menderita kesulitan, maka yang lainnya juga seharusnya merasakan itu. Itulah makna ukhuwah sesungguhnya. Islam mendorong Umatnya untuk menerjemahkan ukhuwah dalam kehidupan sehari-hari. Agar mereka dapat merasakan apa yang diderita saudaranya se-agama, untuk selanjutnya memberikan bantuan apapun bentuknya yang dapat meringankan beban dan penderitaan saudaranya itu.

Semua dalil di atas menunjukkan bahwa apa yang dijelaskan oleh Durkheim mengenai solidaritas sosial telah ada dalam ajaran agama Islam. Maka selanjutnya

VOLUME 1, NO. 2 Juli - Desember 2019 
adalah melihat bagaimana semua pesan persatuan dalam agama mampu diimplementasikan oleh generasi muda Islam di media sosial.

\section{Pemuda Islam dan Media Sosial}

Kaplan \& Haenlein (2010) menjelaskan media sosial sebagai sebuah kelompok aplikasi berbasis internet yang dibangun diatas dasar ideologi dan teknologi Web 2.0, dan memungkinkan penciptaan dan pertukaran user-generated content. Web 2.0 menjadi platform dasar media sosial. Media sosial ada dalam ada dalam berbagai bentuk yang berbeda, termasuk social network, forum internet, weblogs, social blogs, micro blogging, wikis, podcasts, gambar, video, rating, dan bookmark sosial.

Kaplan dan Haenlein (2010) menyebut ada enam jenis media sosial: proyek kolaborasi, blog dan microblogs, komunitas konten, situs jaringan sosial, virtual game, dan virtual social. Berdasarkan definsi tersebut, media sosial memiliki fungsi tertentu, merujuk pada fungsi media, McQuail (Kaplan \& Haenlein, 2010) menyebut bahwa media berfungsi sebagai informasi, kolerasi, dan kesinambungan.

Berdasarkan pemahanan tersebut, tepat 20 Maret 2016 Abdul Wahab, seorang Pemuda Islam yang berasal dari Tegal Jawa Tengah, dibantu teman-temannya meluncurkan situs santrionline.net. Tujuan website tersebut memperkaya khasanah sarana transformasi ilmu dan informasi tentang santri, pesantren, tokoh ulama, Islam ala Aswaja, dan sebagainya di dunia maya. Dalam situs tersebut termuat rubrik antara lain Berita Nasional dan Internasional, Cerita Santri, Profil Pesantren, Kisah Ulama, Kalam Hikmah, Kajian Islam, dan sebagainya. santrionline.net adalah salah satu jawaban dari para santri, atas tantangan modernitas dunia komunikasi-informasi. Situs tersebut memiliki tagline "Dari Santri, Oleh Santri, Untuk Negeri". Untuk mendukung kelancaran website tersebut dibentuklah juga Distro Kang Santri dengan menjaul kaos, kemeja, dan atribut keagamaan yang menempatkan logo Santri Online dan NU.

Website tersebut kemudian dikembangkan ke dalam media sosial Facebook dan Instagram. Hal tersebut dilakukan, Abdul Wahab menilai ada tren arus 
informasi berkembang ke media sosial, khususnya anak muda lebih cenderung ke Instagram. Maka pada tahun 2016, dibuat akun Instagram bernama @ santrionline dengan postingan pertama tanggal 6 Agustus 2016. Pada postingan awal, @ santrionline memberikan ucapan Dirgahayu 71 Indonesiaku, dengan menyampaikan pesan 'jangan lelah mencintai Indonesia' ditambahkan dalam keterangan teks di kolom caption bertuliskan 'karena Indonesia adalah sajadahku'.Postingan awal tersebut sudah menggambarkan apa tujuan lahirnya Santri Online di Instagram. Apalagi dalam informasi biodata tertulis keterangan 'Media Dakwah Santri Indonesia'.

Kedua, setelah kita mengetahui bagaimana perjalanan seorang Abdul Wahab dalam mencetuskan ide Santri Online. Maka penulis selanjutnya akan menjelaskan bagaimana Instagram @santrionline membentuk komunitasnya. Hal yang perlu digarisbawahi dari @ santrionline adalah jatidiri sebagai santri yang melekat. Abdul Wahab selaku pendiri berusaha menempatkan @santrionline untuk berada pada posisi seorang santri yang tidak menggurui. Berbagai informasi yang disebarkan dalam Instagram @santrionline bersifat ilmu pengetahuan yang sumber ilmunya jelas dari ulama atau Kiyai. maka sering dijumpai dalam postingan Instagram @ santrionline muncul tokoh-tokoh Islam yang memberikan ajaran agama untuk dipelajari oleh pengikut @ santrionline. Berbeda dengan akun komunitas Instagram lainnya yang memiliki banyak komentar dari pengikutnya, Instagram @santrionline justru dibentuk dengan pola informasi yang komprehensif. Bukan pada informasi yang menimpulkan banyak pertanyaan dan polemik di media sosial. Tujuan tersebut akhirnya memunculkan fenomena Instagram @santrionline lebih banyak ditonton dan disukai dibandingkan dikomentari. Terkecuali ada postingan yang diberi keterangan 'apabila ada pertanyaan silakan tulis di kolom komentar' maka itu memberikan ruang partisipasi pengikut untuk mengajukan berbagai pertanyaan. Namun hal tersebut bukan berarti apabila ada komentar, @santrionline tidak berkenan untuk menjawab.

Selain menjelaskan isu-isu yang dibangun dalam setiap postingan @ santrionline. Rata-rata informasi yang dibangun adalah kajian-kajian agama 
sebagai solidaritas sosial. NU sebagai organisasi islam yang diafiliasi oleh @ santrionline menampilkan fatwa-fatwa tokoh NU mengenai pentingnya hubungan yang baik antara umat islam dan warga negara Indonesia. Pesan-pesan saling menghormati, toleransi, perdamaian, dan kerukunan ditampilkan dalam periode yang tersebar. Respon terhadap politik di Indonesia juga ditampilkan dengan pesan mengajak rukun antara pendukung Capres 01 dan Capres 02. Selain itu, pesan-pesan mengenai pernikahan juga beberapa kali dibahas dalam @ santrionline. Bagaimana konsep pernikahan seharusnya dimulai dan dijalani ditampilkan dengan informasi yang memadukan hukum agama dan realitas sosial. Pernikahan tidak hanya dilihat dari bahwa agama menganjurkan segera menikah bagi yang sudah dewasa, melainkan hal apa saja yang perlu dipersiapkan untuk menjalani rumah tangga, sehingga potensi perceraian tidak terjadi.

Terakhir, bagian ini yang menurut penulis menjadi poin penting dari keseluruhan catatan di atas. Kelebihan Instagram @ santrionline dengan akun komunitas yang diperuntukkan kepada kalangan pemuda, misalnya akun@shift yang popular menggunakan hashtag \#pemudahijrah. Akun @santrionline membuka diri pada wawasan kebangsaan dan kepatuhan terhadap fatwa-fatwa ulama dan kiyai menjadi ciri khas yang menonjol.

\section{Kesimpulan}

Media sosial, terurama Instagram mampu membentuk solidaritas pemuda islam. Fenomena arus informasi yang begitu mudah di media sosial, tentunya diharapkan pesan persatuan tersebut mampu menggerakkan pemuda islam yang sekarang menguasai dunia maya untuk membangun solidaritas sosial menuju Ketahanan Nasional.

\section{References}

Boyatzis, R. (1998). Transforming qualitative information: Thematic analysis and code development. Thousand Oaks, CA, US: Sage Publications, Inc.

Durkheim, E. (1933). The Division of Labour in Society. (G. Simpson, Trans.) New York: The Macmillan Company.

Geotimes.co.id. (2018, September 28). Ancaman Terhadap Bhinneka Tunggal Ika Di Media Sosial. Retrieved from https://geotimes.co.id/: 
https://geotimes.co.id/event/lomba-menulis/ancaman-terhadap-bhinnekatunggal-ika-di-media-sosial/

Kaplan, A. M., \& Haenlein, M. (2010). Users of The World, Unite! The Challenges and Opportunities of Social Media. Business Horizons, 53, 5968.

Mahmud, A. (2016, November 16). Ancaman Media Sosial. Retrieved from https://www.kompasiana.com/:

https://www.kompasiana.com/amirudinmahmud/582b91ef359773b810c90 745/ancaman-media-sosial

Riski, P. (2018, September 1). Berita Hoaks, Ancaman Serius Persatuan Bangsa Memasuki Tahun Politik. Retrieved from https://www.voaindonesia.com: https://www.voaindonesia.com/a/berita-hoaks-ancaman-serius-persatuanbangsa-memasuki-tahun-politik/4553726.html

Rochmanudin. (2018, Februari 19). [Linimasa] Kasus Intoleransi dan Kekerasan Beragama Sepanjang 2018. Retrieved from https://www.idntimes.com: https://www.idntimes.com/news/indonesia/rochmanudin-wijaya/linimasakasus-intoleransi-dan-kekerasan-beragama-sepanjang-2/full

Wardi, R. (2018, Februari 22). Kasad: Perpecahan Bangsa Menjadi Ancaman Serius. Retrieved from https://www.beritasatu.com: https://www.beritasatu.com/nasional/479773/kasad-perpecahan-bangsamenjadi-ancaman-serius 